\title{
KETERLIBATAN MAHASISWA KEDOKTERAN UNIVERSITAS SEBELAS MARET DALAM UPAYA MITIGASI WABAH COVID-19 DI KOMUNITAS
}

\author{
Abdurrahman Ghiyaats, Arifa Sherina Noor S., Aulia Sholiha, Almira Kirana R., Annisa' \\ Nahdah, Aulia Rahman, Amira Masiah S.
}

\begin{abstract}
ABSTRAK
Wabah COVID-19 merupakan bencana nonalam yang terjadi secara global sejak awal tahun 2020. Laju penularan yang cepat dan kemungkinan komplikasi yang fatal menyebabkan tingginya angka kematian akibat COVID-19. Sejak penemuan kasus pertama COVID-19, berbagai upaya penanganan dan penanggulangan COVID-19 terus dilakukan. Keberhasilan pengembangan vaksin COVID-19 memberikan harapan baru dalam eradikasi COVID-19, namun disisi lain dapat mengganggu stabilitas dalam masyarakat dikarenakan kebijakan yang terus berganti demi tercapainya target cakupan vaksin dalam waktu singkat, kurangnya pengetahuan masyarakat terhadap kebijakan yang berlaku, serta rentannya terjadi misinformasi di kalangan masyarakat. Oleh karena itu, diperlukan sumber daya manusia tambahan untuk dapat memaksimalkan pelayanan kesehatan dalam penanganan dan penanggulangan COVID-19. Mahasiswa kedokteran memiliki kedudukan yang strategis untuk dilibatkan dalam upaya mitigasi wabah COVID-19. Hal ini dikarenakan mahasiswa kedokteran telah mendalami ilmu-ilmu kedokteran dasar dan berstatus sebagai bagian dari komunitas itu sendiri. Institusi pendidikan kedokteran, salah satunya Fakultas Kedokteran Universitas Sebelas Maret mewadahi mahasiswanya untuk berperan dalam komunitas sesuai dengan kompetensi yang dimiliki melalui penyelenggaraan KKN Tematik yang bertepatan dengan pelaksanaan program Serbuan Vaksinasi COVID-19 Universitas Sebelas Maret.
\end{abstract}

Kata Kunci: KKN Tematik, COVID-19, vaksinasi, proyek, komunitas

\section{Pendahuluan}

Coronavirus disease sembilan belas atau COVID-19 merupakan penyakit infeksi yang disebabkan oleh varian baru virus dari golongan Coronaviridae yang umumnya ditandai dengan gejala gangguan pernapasan ringan hingga sedang, namun dapat berkembang menjadi penyakit serius pada penderita dengan faktor komorbid (World Health Organization (WHO), 2020). Per 29 Agustus 2021, terdapat lebih dari dua ratus juta kasus terkonfirmasi dan lebih dari empat juta empat ratus kasus pasien meninggal telah dilaporkan (WHO, 2021). Sifat alamiah virus Sars-Cov-2 yang terus berevolusi (Lauring \& Hodcroft, 2020; Callaway, 2020), hingga mampu menimbulkan dampak yang berbeda bagi penderita satu dengan yang lainnya membuat eradikasi COVID-19 menjadi tantangan tersendiri bagi umat manusia.

Vaksinasi memiliki artian suatu proses didalam tubuh dimana timbul kekebalan seseorang secara aktif terhadap suatu penyakit, sehingga apabila suatu saat terpapar dengan penyakit tersebut tidak akan sakit atau sakit ringan dan tidak menjadi sumber penularan (Kementrian Kesehatan Republik Indonesia, 2021). Vaksinasi dilakukan dengan pemberian vaksin, yakni produk biologi yang berisi antigen berupa mikroorganisme tertentu atau bagiannya atau zat lain yang dihasilkannya dan telah diolah sehingga aman untuk digunakan. Terdapat empat jenis vaksin COVID-19 yang berhasil dikembangkan, antara lain vaksin virus utuh (whole virus vaccine), vaksin asam nukleat (nucleic acid vaccine), vaksin subunit protein, dan 
vaksin dengan vektor virus (viral vector-based vaccine). Whole Virus Vaccine atau vaksin virus utuh menggunakan virus yang telah dilemahkan (live attenuated vaccine) yang dapat tumbuh dan bereplikasi tanpa menimbulkan penyakit, atau virus yang materi genetiknya telah dihancurkan (innactivated vaccine) sehingga virus tidak bisa menginfeksi sel dan bereplikasi (Global Alliance for Vaccines and Immunization (GAVI), 2020).

Vaksin subunit protein merupakan vaksin yang dikembangkan berdasarkan peptida sintetik atau protein rekombinan, dimana vaksin jenis ini memuat fragmen antigen spesifik dari virus, namun tidak memuat materi infeksius dari virus (Wang, et al., 2020). Vaksin asam nukleat memanfaatkan materi genetik (RNA atau DNA) virus yang memuat instruksi untuk penyusunan protein spesifik virus yang dapat dikenali sistem imun sebagai antigen (GAVI, 2020). Viral vector-based vaccine atau vaksin dengan vektor virus menggunakan virus yang telah dimodifikasi sebagai 'vektor' untuk memasukkan kode genetik untuk antigen patogen, misal protein spike yang ditemukan pada permukaan Sars-Cov-2, ke dalam sel tubuh manusia hingga akhirnya dapat memicu sel tubuh yang terinfeksi untuk memproduksi antigen dalam jumlah besar dan menimbulkan respon imun identik dengan proses infeksi alami patogen dalam tubuh (Zhu, et al., 2020).

Untuk dapat disetujui pihak berwenang dan digunakan secara publik, kandidat vaksin akan melalui proses panjang yang meliputi fase eksploratori (penelitian dasar produk yang akan digunakan, fase uji pra-klinis (uji coba efektivitas pada hewan coba), fase uji klinis, peninjauan pengaturan dan persetujuan vaksin, manufaktur, dan kontrol kualitas (Centers for Disease Control and Prevention (CDC), 2020). Fase uji klinis dalam pengembangan obat-obatan dan termasuk vaksin, selanjutnya dibagi menjadi empat fase, yakni uji klinis fase I dengan jumlah subjek 20-100 orang sehat atau dengan penyakit/kondisi yang berkaitan, uji klinis fase II dengan jumlah subjek ratusan dengan penyakit/kondisi yang berkaitan, uji klinis fase III dengan jumlah subjek 300 hingga 3000 orang dengan penyakit/kondisi yang berkaitan, serta uji klinis fase IV dengan jumlah subjek ribuan orang dengan penyakit/kondisi yang berkaitan untuk mempelajari keamanan dan efikasi obat/vaksin (Food and Drug Administration (FDA), 2018). Uji klinis dalam pengembangan vaksin, khususnya vaksin terhadap penyakit menular, membutuhkan waktu hingga beberapa tahun, namun vaksin COVID-19 merupakan vaksin pertama dalam sejarah yang dikembangkan hanya dalam hitungan bulan. Hingga 27 Agustus 2021, terdapat 184 kandidat vaksin yang sedang berada dalam tahap uji pra-klinis dan 112 kandidat vaksin yang sedang berada dalam tahap uji klinis, 8 diantaranya telah memasuki uji klinis fase IV (WHO, 2021).

Pada 13 Januari 2021, pemerintah Indonesia mulai memberlakukan program vaksinasi COVID19 setelah dua hari sebelumnya, Persetujuan Penggunaan dalam Kondisi Darurat atau Emergency Use Authorization (EUA) diterbitkan oleh Badan Pengawasan Obat dan Makanan (BPOM) untuk vaksin COVID-19 Coronavac yang diproduksi oleh Sinovac Biotech asal Tiongkok (Direktorat Jenderal Pencegahan dan Pengendalian Penyakit (Ditjen P2P), 2021). EUA selanjutnya diterbitkan oleh BPOM berturut-turut untuk vaksin COVID-19 produksi PT. Bio Farma (16 Febuari 2021); vaksin COVID-19 AstraZeneca produksi SK Bioscience Co. Ltd. asal Korea (9 Maret 2021); vaksin COVID-19 produksi Beijing Bio-Institute Biological Products Co. (Sinopharm) yang berada dalam nama Sars-Cov-2 Vaccine Vero Cell, Inactivated (30 April 2021); vaksin Comirnaty produksi Pfizer \& BioNTech (15 Juli 2021); dan vaksin COVID-19 Sputnik-V yang dikembangkan oleh The Gamaleya National Center of Epidemiology and Microbiology, Rusia (25 Agustus 2021) ( Badan Pengawasan Obat dan Makanan (BPOM), 2021). 
Pengaruh vaksin terhadap kejadian COVID-19 telah terbukti melalui penelitian. Studi menunjukkan bahwa penurunan tingkat fatalitas kasus atau Case Fatality Rate (CFR) COVID-19 terjadi secara signifikan setelah cakupan vaksin COVID-19 di suatu daerah mencapai 8\%, dengan angka penurunan CFR sebesar 7,6\% setiap 10\% kenaikan cakupan vaksin COVID-19 (Liang, et al., 2021). Sementara data dari Kementrian Kesehatan Kesehatan Republik Indonesia menunjukkan adanya perbedaan tingkat perawatan akibat infeksi COVID-19 antara tenaga kesehatan yang belum menerima vaksin COVID-19 dan tenaga kesehatan yang telah menerima vaksin dosis 1 dan 2 . Pada kelompok tenaga kesehatan yang belum menerima vaksin proporsi tenaga kesehatan yang dirawat adalah sebesar 0,35\%, sedangkan pada kelompok tenaga kesehatan yang telah menerima vaksinasi dosis lengkap adalah sebesar 0,17\% (Kementrian Kesehatan Republik Indonesia, 2021).

Kementrian Kesehatan Republik Indonesia sedang mengupayakan terwujudnya target dua juta vaksinasi COVID-19 per hari, mengutip pernyataan Juru Bicara Vaksinasi COVID-19 kepada Kompas.com (Sari, 2021). Dalam rangka perwujudan target tersebut, Universitas Sebelas Maret (UNS) Surakarta, bekerja sama dengan Komando Resor Militer (Korem) 074/Warastratama dan Detasemen Kesehatan Wilayah (Denkesyah) 04.04.04 Surakarta, mengadakan program Serbuan Vaksinasi COVID19 UNS. Program ini dilaksanakan pada bulan Juli hingga Agustus 2021 dan memungkinkan tersedianya layanan kesehatan vaksinasi COVID-19 untuk mahasiswa, civitas, keluarga civitas UNS, serta masyarakat sekitar. Dalam pelaksanaannya, program Serbuan Vaksinasi COVID-19 melibatkan peran dokter-dokter lulusan FK UNS, dokter muda FK UNS, dan mahasiswa program studi Kedokteran Fakultas Kedokteran (FK) UNS yang tergabung dalam program Kuliah Kerja Nyata (KKN) Tematik FK UNS 2021. KKN Tematik FK UNS 2021 merupakan kegiatan yang diselerenggarakan oleh FK UNS untuk memfasilitasi mahasiswa Kedokteran FK UNS untuk mengabdi kepada masyarakat di era COVID-19.

Melalui keikutsertaan dalam KKN Tematik FK UNS 2021, mahasiswa diberikan peluang untuk berpartisipasi aktif pada pelaksanaan program Serbuan Vaksinasi UNS 2021 sebagai bagian dari panitia penyelenggara kegiatan. Mahasiswa dapat mengetahui sistem kesehatan yang ada di Indonesia seputar pandemi dan mendalami proses vaksinasi dengan menyaksikannya secara langsung. Mahasiswa juga diharapkan dapat melatih kemampuan berkomunikasi dan sambung rasa dengan pasien selama kegiatan KKN berlangsung. Disamping menggerakkan mahasiswa untuk terjun ke masyarakat dalam pelayanan vaksinasi COVID-19, KKN Tematik FK UNS memberikan kesempatan untuk mengaplikasikan ilmu kedokteran komunitas melalui proyek kelompok kecil yang dapat disusun dan dieksekusi menurut kreativitas mahasiswa sendiri.

\section{Persiapan Kegiatan}

Untuk mendukung pelaksanaan program KKN Tematik FK UNS 2021, mahasiswa melakukan berbagai kegiatan persiapan dibawah ini:

\section{a. Technical Meeting}

Technical Meeting pertama dilaksanakan pada 13 Juli 2021 melalui aplikasi Zoom Meeting dan melibatkan seluruh mahasiswa yang terdaftar sebagai peserta KKN Tematik FK UNS. Technical Meeting diisi dengan agenda pemaparan latar belakang kegiatan vaksinasi, penjelasan teknis pelaksanaan kegiatan vaksinasi, serta pembagian job description. Pemaparan dilakukan oleh perwakilan peserta yang sebelumnya telah mendapatkan materi dari pihak dekanat. 
Peserta KKN Tematik FK UNS selanjutnya dibagi dalam empat kelompok besar, yaitu kelompok A, kelompok B, kelompok $\mathrm{C}$, dan kelompok D, dengan masing-masing kelompok beranggotakan lima puluh lima hingga enam puluh orang.

\section{b. Pertemuan Briefing Menjelang Pelaksanaan Acara}

Secara rutin setiap minggu sebelum bertugas, pertemuan akan dilaksanakan untuk satu kelompok besar dalam rangka penyampaian briefing untuk hari $\mathrm{H}$ pelaksanaan, evaluasi minggu sebelumnya, serta pemberitahuan apabila terdapat perubahan jadwal maupun penyesuaian dalam kegiatan vaksinasi. Pertemuan ini dilaksanakan secara virtual melalui Zoom Meeting. Dalam pertemuan ini, setiap anggota memiliki hak untuk mengajukan pertanyaan, memberikan masukan, dan menyampaikan evaluasi yang dimiliki terhadap pelaksanaan kegiatan vaksin di minggu sebelumnya.

\section{c. Bimbingan dengan dosen pembimbing}

Dekanat FK UNS mengerahkan sejumlah dokter sebagai tenaga pengajar untuk membimbing dan pengawasi mahasiswa dalam pelaksanaan kegiatan KKN Tematik FK UNS 2021. Untuk mempermudah komunikasi antara dosen pembimbing dan mahasiswa, kelompok besar yang sudah dijelaskan diatas kemudian dipecah menjadi empat kelompok kecil dan selanjutnya masing-masing kelompok kecil tersebut akan dibimbing oleh satu orang dosen pembimbing.

Pertemuan kelompok D1 dengan dosen pembimbing dilakukan di awal, pertengahan, dan akhir periode KKN Tematik FK UNS. Pertemuan tersebut berisi pengarahan yang diberikan oleh dosen pembimbing, kondisi di lingkungan FK UNS dan upaya FK UNS selama masa pandemi, penyampaian masukan oleh dosen pembimbing terkait usulan dan pelaksanaan peoject kelompok kecil, serta evaluasi dosen pembimbing mengenai seluruh dokumen penugasan.

\section{d. Pertemuan kelompok kecil}

Kelompok D1 melakukan pertemuan-pertemuan secara tentatif sepanjang periode KKN Tematik FK UNS. Pertemuan diisi dengan diskusi antar anggota mengenai proyek kelompok kecil dan penyusunan dokumen penugasan serta media yang diperlukan untuk eksekusi proyek kelompok kecil.

\section{Metode Pelaksanaan}

\section{a. Pelaksanaan Vaksinasi}

Serbuan Vaksinasi FK UNS merupakan kegiatan vaksinasi yang diselenggarakan oleh Fakultas Kedokteran Universitas Sebelas Maret dengan Datasemen Kesehatan Wilayah 04.04.04, Klinik Pratama Kartika I - 01, Surakarta sebagai penyedia vaksin. Kegiatan ini bertujuan untuk memberikan fasilitas vaksinasi massal yang aman dan berkualitas bagi masyarakat Solo, terutama civitas akademik UNS. Kegiatan vaksinasi ini dilaksanakan 24 kali dari 1 Juli 2021 hingga 20 Agustus 2021 serta mencakup vaksinasi dosis pertama dan kedua. Auditorium dan Lobi Gedung Pendidikan Dokter, FK UNS telah disiapkan sedemikian rupa agar dapat menjadi tempat penyelenggaraan vaksinasi yang ideal.

Fakultas Kedokteran UNS mengajak mahasiswa Program Studi Kedokteran semester 4, semester 6, dokter muda, serta dokter umum maupun spesialis untuk berperan aktif dalam menyediakan pelayanan yang optimal selama vaksinasi. Setiap pihak yang terlibat tersebut telah mendapatkan pelatihan sebelumnya untuk meminimalisir terjadinya hal-hal yang tidak diinginkan. Pembagian peran dan tanggung jawab dalam kepanitiaan vaksinasi juga disesuaikan dengan kompetensi masing-masing. Mahasiswa bertugas pada bagian hubungan masyarakat, registrasi, pengecekan tekanan darah dan suhu, observasi pasca vaksin, serta administrasi pasca vaksin. Dokter muda dan dokter umum maupun spesialis bertugas dalam skrining kesehatan, penginjeksian vaksin, 
serta penanganan kejadian ikutan pasca imunisasi (KIPI). Alur kegiatan vaksinasi dari tahap persiapan hingga pelaksanaan dan evaluasi dapat diuraikan sebagai berikut:

- Rapat persiapan bersama panitia dan penyelenggara

- Pengambilan vaksin di Klinik Pratama Kartika I - 01

- Persiapan lokasi vaksinasi

- Persiapan dan pembagian tugas panitia vaksinasi

- Penyebarluasan informasi pendaftaran ke civitas akademik UNS dan masyarakat Solo melalui berbagai media seperti Instagram, WhatsApp, Telegram, dan Line

- Pendaftaran calon peserta vaksinasi melalui formulir Google beberapa hari sebelum kegiatan vaksinasi dimulai

- Penyeleksian calon peserta berdasarkan riwayat kesehatan dan ketersediaan kuota oleh panitia vaksinasi, khususnya bagian Humas dan IT

- Peserta yang terseleksi akan menerima berkas vaksinasi yang berisi undangan vaksinasi dan dokumen penting lainnya melalui surel pribadi yang dikirim oleh Humas dan IT

- Peserta kemudian datang ke FK UNS untuk melakukan vaksinasi. Data peserta akan dicatat di bagian registrasi

- Pengecekan suhu dan tekanan darah. Jika peserta memiliki suhu dan tekanan darah yang normal, peserta dapat lanjut ke bagian skrining kesehatan.

- Skrining kondisi kesehatan oleh dokter muda dan dokter umum maupun spesialis. Jika peserta dinyatakan sehat dan siap vaksinasi, maka peserta dapat melanjutkan vaksinasi. Jika peserta tidak memenuhi syarat kondisi kesehatan yang teah ditentukan oleh Kementerian Kesehatan RI, maka vaksinasi ditunda agar tidak terjadi kejadian yang tidak diinginkan.

- Penginjeksian vaksin oleh dokter muda dan dokter umum maupun spesialis

- Setelah vaksinasi, peserta tetap berada di ruangan observasi selama sekitar 30 menit untuk mengantisipasi terjadinya KIPI. Jika terjadi KIPI, maka peserta akan dibawa ke ICU dan dirawat oleh dokter yang berjaga.

- Administrasi dilakukan setelah vaksinasi selesai sehingga peserta sudah mendapatkan sertifikat vaksin sebelum pulang.

\section{b. Pelaksanaan Proyek Kelompok Kecil}

Kelompok D1 mengangkat topik 'Penanganan Sesak Napas di Era COVID-19' dan 'Penggunaan Aplikasi SIRANAP' sebagai muatan untuk proyek kelompok kecil. Proyek kelompok kecil D1 mencakup beberapa aktivitas, antara lain:

1. Pembuatan poster edukasi 'Penanganan Sesak Napas di Era COVID-19' dan 'Penggunaan Aplikasi SIRANAP' yang akan ditempatkan di Auditorium FK UNS sebagai lokasi pelaksanaan kegiatan vaksinasi

2. Sosialisasi 'Penanganan Sesak Napas di Era COVID-19' dan 'Penggunaan Aplikasi SIRANAP' kepada peserta vaksinasi

3. Penyebaran informasi melalui media sosial mengenai 'Penanganan Sesak Napas di Era COVID19' dan 'Penggunaan Aplikasi SIRANAP' serta kampanye penggunaan aplikasi SIRANAP Pemilihan 'Penanganan Sesak Napas di Era COVID-19' dan 'Penggunaan Aplikasi SIRANAP' sebagai topik dikarenakan sesak napas atau dyspnea yang merupakan manifestasi infeksi COVID-19 yang paling sering dilaporkan dibandingkan dengan gejala lainnya seperti rasa lelah dan demam (Nasserie, Hittle, \& Goodman, 2021), serta urgensi bagi masyarakat untuk mengetahui derajat 
keparahan sesak napas yang diderita untuk mempertimbangkan membawa pasien ke rumah sakit untuk menerima pertolongan. Aplikasi SIRANAP memegang peran penting selama pandemi COVID-19 dalam memberikan informasi mengenai rumah sakit terdekat dan ketersediaan layanan perawatan COVID-19. Dengan mengangkat dua topik tersebut, proyek kecil kelompok D1 turut memberikan dukungan terhadap upaya pemerintah dalam menurunkan Bed Occupancy Rate (BOR) di rumah sakitrumah sakit sebagai langkah untuk memaksimalkan pelayanan kesehatan dalam mitigasi COVID-19.

Campaign atau kampanye memiliki kedudukan sebagai kegiatan pelengkap layanan kesehatan untuk mencapai cakupan populasi yang lebih besar (WHO \& United Nations Children's Fund (UNICEF), 2020). Kampanye penggunaan aplikasi SIRANAP yang dilakukan kelompok D1 bertujuan untuk meningkatkan eksistensi aplikasi SIRANAP diantara masyarakat luas. Media sosial dipilih sebagai wadah kampanye penggunaan aplikasi SIRANAP dikarenakan hasil survei yang menunjukkan bahwa 82,3\% pengguna internet di Indonesia menerima informasi seputar COVID-19 melalui media sosial (Balai Pengembangan Sumber Daya Manusia dan Penelitian Komunikasi dan Informatika Kementrian Informasi, 2020).

\section{c. Kegiatan Komplementer Lainnya}

Sebagai pelengkap, peserta KKN Tematik FK UNS 2021 sangat dianjurkan untuk mengikuti webinar-webinar dengan tema seputar COVID-19 selama periode KKN berlangsung. Pihak fakultas secara berkala memberikan undangan acara webinar, khususnya webinar dengan materi vaksinasi, yang dapat dihadiri mahasiswa. Kegiatan komplementer lain dalam KKN Tematik FK UNS 2021 yakni mahasiswa dapat ikut serta menjadi relawan vaksinasi dalam kepanitiaan vaksinasi COVID-19 masyarakat diluar Serbuan Vaksinasi yang diselenggarakan oleh UNS atas rekomendasi Fakultas.

\section{d. Monitoring dan Evaluasi}

Monitoring atau pengawasan melibatkan peserta KKN Tematik FK UNS 2021 yang telah ditunjuk sebagai koordinator tim dan Dosen Pembimbing Lapangan atau DPL. Pengawasan dilakukan untuk mengantisipasi kesalahan teknis yang mungkin terjadi selama kegiatan vaksinasi berlangsung. Sedangkan evaluasi dilakukan pada agenda pertemuan dan briefing kelompok besar yang dilaksanakan setiap minggu dan. Setiap evaluasi akan dicatat dan solusi yang ditemukan akan menjadi rekomendasi dalam kegiatan selanjutnya atau untuk kelompok besar lain yang akan bertugas.

\section{Hasil dan Pembahasan}

\section{a. Laporan Pelaksanaan Vaksinasi}

Pelaksanaan vaksinasi merupakan kegiatan utama dari KKN Tematik Kemanusiaan: Relawan COVID-19 yang bertujuan untuk membantu menanggulangi pandemi COVID-19 melalui pembentukan kekebalan massa dan memperkecil risiko kejadian kasus COVID-19 dengan gejala berat maupun kritis. Kegiatan vaksinasi dosis pertama dan kedua dilaksanakan pada Auditorium dan Lobi Gedung Pendidikan Dokter, FK UNS sebanyak 24 kali pada tanggal seperti tertera pada tabel 1. Mahasiswa dan dokter yang bertugas setiap harinya digilir agar setiap individu memiliki waktu istirahat yang cukup sehingga memperkecil risiko tertular COVID-19 dari peserta maupun sesama panitia. Panitia dibagi menjadi empat tim besar, yaitu Tim A, B, C, dan D. Dalam satu hari vaksinasi, dua tim akan bertugas dalam shift yang berbeda. Pembagian tim juga dapat dilihat pada tabel 1.

Untuk meminimalisir risiko penularan COVID-19 saat vaksinasi, panitia juga diwajibkan memakai APD lengkap mulai dari headcap, dua masker, face shield, gown, dan sarung tangan medis. Peserta juga telah dihimbau untuk menggunakan dua masker dan selalu menjaga jarak dengan peserta lain di FK UNS. Area cuci tangan dengan air dan sabun maupun hand sanitizer telah tersedia di banyak 
titik yang mencakup semua alur vaksinasi di FK UNS. Peserta juga diwajibkan untuk datang sesuai dengan jam dan kloter yang telah dibagi sebelumnya untuk menghindari terjadinya kerumunan.

Selain panitia yang berperan langsung dalam rangkaian alur vaksinasi, banyak juga pihak yang berperan penting dalam terlaksananya vaksinasi di FK UNS, diantaranya satpam, petugas kebersihan, petugas konsumsi, penyedia tabung oksigen, serta petugas listrik dan internet. Akses internet menjadi hal yang krusial dalam penyelenggaraan vaksinasi karena setiap petugas di tiap alur vaksinasi (registrasi, pengukuran suhu dan tekanan darah, skrining kondisi kesehatan, vaksinasi, observasi, dan administrasi) wajib melakukan input data pada sebuah sistem yang terintegrasi secara real time. Hal tersebut dilakukan untuk mempersingkat waktu tunggu, efisiensi tenaga, dan melakukan pendataan yang lengkap dan sesuai dengan kebutuhan dari Kementrian Kesehatan RI.

Tabel 1. Jadwal Vaksinasi di Fakultas Kedokteran UNS

\begin{tabular}{|c|c|c|c|}
\hline \multicolumn{2}{|c|}{ Dosis Pertama } & \multicolumn{2}{|c|}{ Dosis Kedua } \\
\hline Tanggal & Panitia & Tanggal & Panitia \\
\hline 1 Juli 2021 & Sukarela & \multirow{2}{*}{5 Agustus 2021} & \multirow{2}{*}{ Tim C dan D } \\
\hline 3 Juli 2021 & Sukarela & & \\
\hline 5 Juli 2021 & Sukarela & 7 Agustus 2021 & Tim A dan B \\
\hline 9 Juli 2021 & Sukarela & 8 Agustus 2021 & Tim C dan D \\
\hline 12 Juli 2021 & Sukarela & 9 Agustus 2021 & Tim A dan B \\
\hline 14 Juli 2021 & Tim A dan B & 10 Agustus 2021 & Tim C dan D \\
\hline 15 Juli 2021 & Tim C dan D & \multirow{2}{*}{12 Agustus 2021} & \multirow{2}{*}{ Tim A dan B } \\
\hline 16 Juli 2021 & Tim A dan B & & \\
\hline 17 Juli 2021 & Tim $C$ dan D & 14 Agustus 2021 & Tim C dan D \\
\hline 21 Juli 2021 & Tim A dan B & 18 Agustus 2021 & Tim A dan B \\
\hline 22 Juli 2021 & Tim $C$ dan D & \multirow{2}{*}{19 Agustus 2021} & \multirow{2}{*}{ Tim $C$ dan D } \\
\hline 23 Juli 2021 & Tim A dan B & & \\
\hline 24 Juli 2021 & Tim $C$ dan D & \multirow{2}{*}{20 Agustus 2021} & \multirow{2}{*}{ Tim A dan B } \\
\hline 26 Juli 2021 & Tim A dan B & & \\
\hline
\end{tabular}

Antusiasme yang besar dari civitas akademik UNS dan masyarakat Solo dalam kegiatan vaksinasi ini dapat dilihat dari jumlah pendaftar vaksin setiap harinya yang sering melebihi kuota yang disediakan. Peserta yang telah mendaftar dan melakukan registrasi di FK UNS belum tentu melanjutkan vaksinasi dikarenakan oleh beberapa hal diantaranya adanya riwayat terinfeksi COVID19 kurang dari tiga bulan, hamil, atau memiliki tekanan darah tinggi. Jumlah peserta yang melakukan registrasi dan jumlah peserta yang tervaksin setiap harinya dapat dilihat pada tabel berikut.

Kegiatan vaksinasi terlaksana dengan baik sesuai dengan alur yang telah direncanakan pada bagian sebelumnya yaitu mulai dari persiapan panitia, persiapan lokasi, penyebaran informasi, pendaftaran peserta hingga registrasi peserta di FK UNS, pengecekan suhu dan tekanan darah, skrining kondisi kesehatan, vaksinasi, observasi, dan administrasi pasca vaksinasi. Observasi KIPI tidak hanya dilakukan di tempat vaksinasi, tetapi juga dipantau secara daring melalui WhatsApp oleh mahasiswa FK UNS yang sedang bertugas. Hal tersebut bertujuan untuk membantu menyediakan penanganan yang cepat dan tepat jika terjadi KIPI di luar FK UNS serta memberikan edukasi kepada masyarakat terkait KIPI. Dokumentasi kegiatan vaksinasi FK UNS dapat dilihat pada gambar 1. 
Tabel 2. Jumlah Peserta Teregistrasi dan Tervaksin di Fakultas Kedokteran UNS

\begin{tabular}{|c|c|c|}
\hline Tanggal & PESERTA REGISTRASI & TOTAL PESERTA TERVAKSIN \\
\hline 1 Juli 2021 & 533 & 411 \\
\hline 3 Juli 2021 & 1564 & 1257 \\
\hline 5 Juli 2021 & 1131 & 864 \\
\hline 9 Juli 2021 & 1131 & 1020 \\
\hline 12 Juli 2021 & 1231 & 1077 \\
\hline 14 Juli 2021 & 1214 & 1046 \\
\hline 15 Juli 2021 & 1222 & 948 \\
\hline 16 Juli 2021 & 1340 & 1066 \\
\hline 17 Juli 2021 & 1400 & 883 \\
\hline 21 Juli 2021 & 1262 & 948 \\
\hline 22 Juli 2021 & 1225 & 951 \\
\hline 23 Juli 2021 & 1419 & 1192 \\
\hline 24 Juli 2021 & 1654 & 1337 \\
\hline 26 Juli 2021 & 1517 & 1245 \\
\hline 5 Agustus 2021 & 1731 & 1355 \\
\hline 7 Agustus 2021 & 1110 & 968 \\
\hline 8 Agustus 2021 & 953 & 863 \\
\hline 9 Agustus 2021 & 1109 & 998 \\
\hline 11 Agustus 2021 & 979 & 906 \\
\hline 12 Agustus 2021 & 919 & 856 \\
\hline 14 Agustus 2021 & 1801 & 1782 \\
\hline 18 Agustus 2021 & 1095 & 1008 \\
\hline 19 Agustus 2021 & 2108 & 2008 \\
\hline 20 Agustus 2021 & 2535 & 2401 \\
\hline TOTAL & $\mathbf{2 7 8 2 4}$ & \\
\hline
\end{tabular}

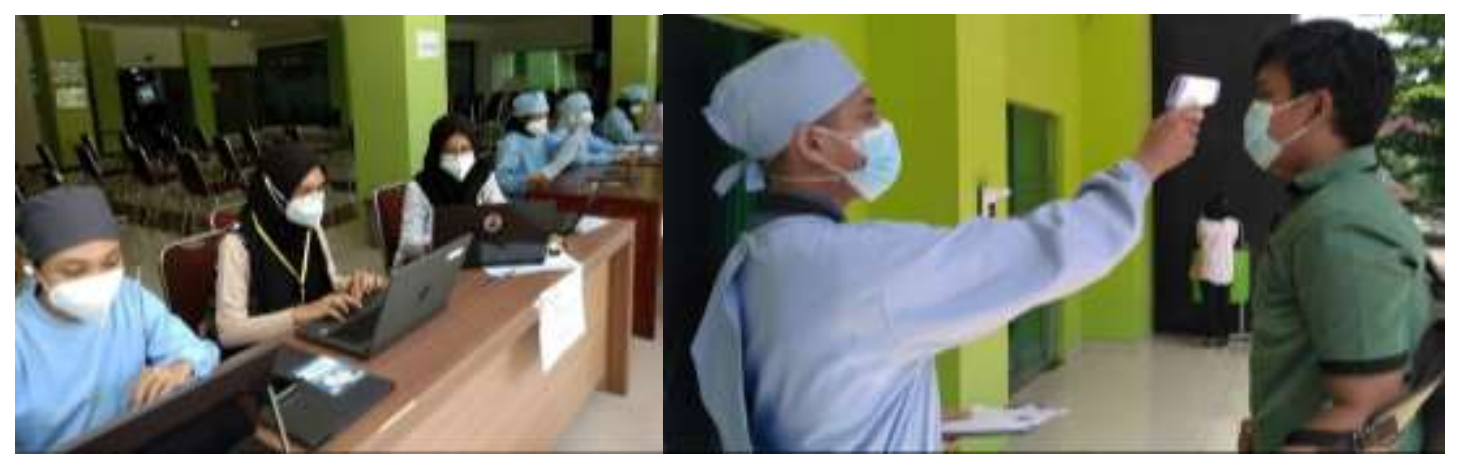




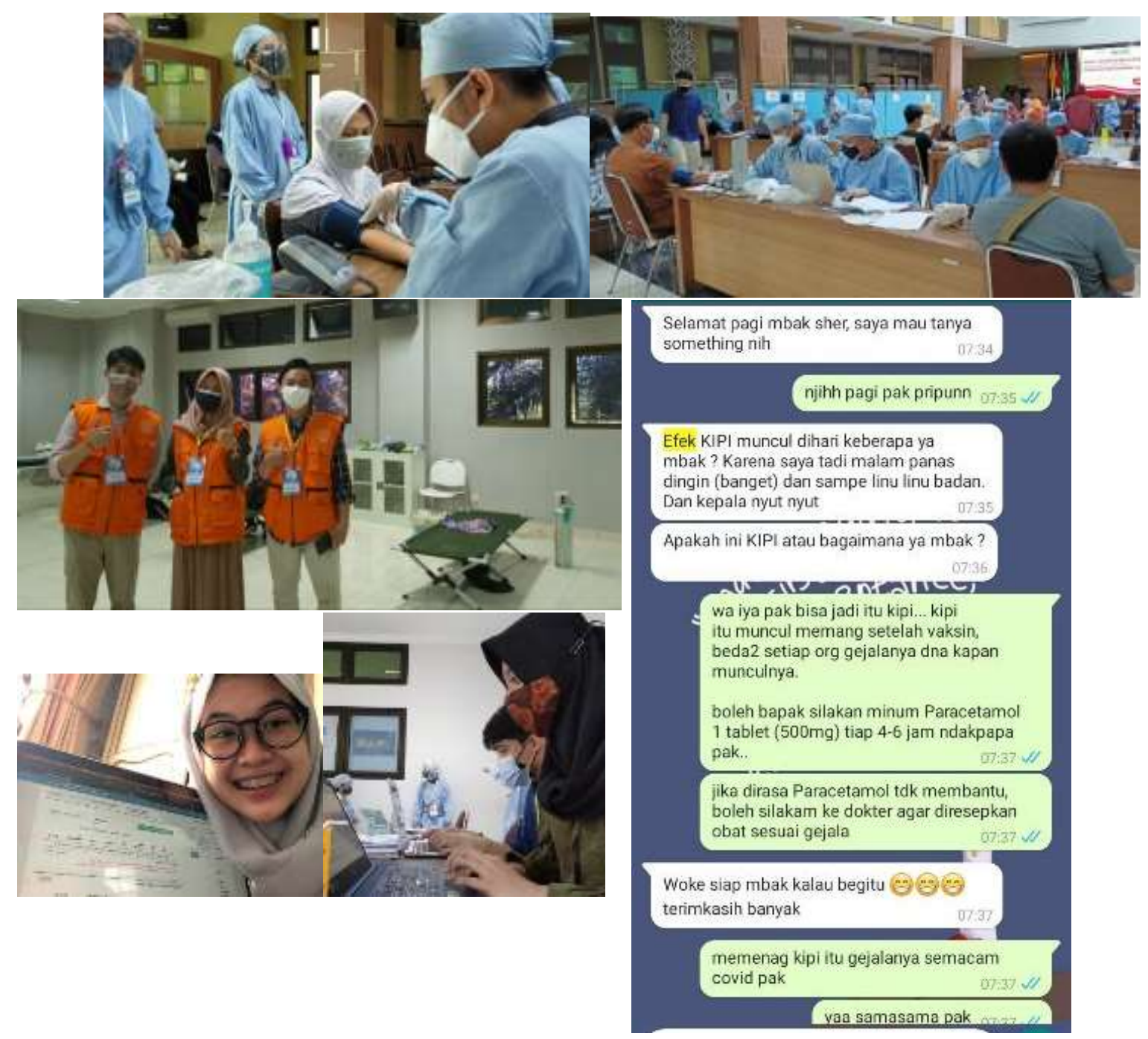

Gambar 1. Dokumentasi Pelaksanaan Vaksinasi (Registrasi, Pengecekan Suhu dan Tekanan Darah, Skrining Kondisi Kesehatan, Vaksinasi, Observsi KIPI (Setelah Vaksin dan Beberapa Hari Setelahnya), serta Adiminstrasi Sertifikat)

\section{b. Laporan Pelaksanaan Proyek Kelompok}

Selain pelaksanaan vaksinasi, setiap mahasiswa diperbolehkan membuat berbagai proyek tambahan bersama dengan kelompok kecil maupun secara individu selama KKN Tematik Kemanusiaan: Relawan COVID-19 berlangsung. Kegiatan tambahan yang dilakukan oleh kelompok D1 adalah edukasi ke masyarakat terkait sesak napas dan sistem informasi rawat inap (SIRANAP). Kedua tema tersebut dipilih karena urgensi masyarakat untuk memahami gejala COVID-19 yang perlu diwaspadai yaitu salah satunya sesak napas serta mengetahui cara mencari rumah sakit atau fasilitas pelayanan kesehatan rujukan COVID-19. Kegiatan edukasi dilakukan dua kali, yaitu secara luring dan daring. Edukasi secara luring dilakukan pada hari Rabu, 18 Agustus 2021 dari pukul 09.00 WIB hingga pukul 16.00 WIB, sedangkan edukasi secara daring dilakukan pada hari Kamis, 19 Agustus 2021 dan Sabtu, 21 Agustus 2021 selama 24 jam. 
Sasaran dari kegiatan edukasi secara luring adalah masyarakat yang sedang menunggu di ruang observasi KIPI setelah vaksinasi, sedangkan sasaran edukasi secara daring adalah masyarakat umum yang lebih luas. Penyampaian materi edukasi secara luring menggunakan media berupa banner dan Slideshow Power Point, sedangkan materi edukasi daring disampaikan melalui akun Instagram masing-masing anggota dan akun Instagram vaksinasifkuns yang merupakan akun resmi kegiatan vaksinasi di FK UNS. Hal tersebut dilakukan untuk menjangkau masyarakat yang lebih luas. Materi edukasi diambil dari sumber yang terpercaya dan evidence-based sehingga informasi yang disampaikan ke masyarakat dapat diterapkan di kehidupan masa pandemi. Dokumentasi terkait edukasi secara luring maupun daring dapat dilihat pada gambar 2 dan 3.

Masyarakat yang menerima edukasi memberikan respon yang baik. Pada edukasi secara luring, banyak masyarakat yang mencatat materi yang diberikan, serta pada eduaksi secara daring, banyak masyarakat yang memberikan respon melalui likes atau pertanyaan-pertanyaan terkait materi yang disampaikan. Hal tersebut menunjukkan bahwa informasi mengenai penanganan sesak napas dan SIRANAP dibutuhkan oleh masyarakat pada masa pandemi.

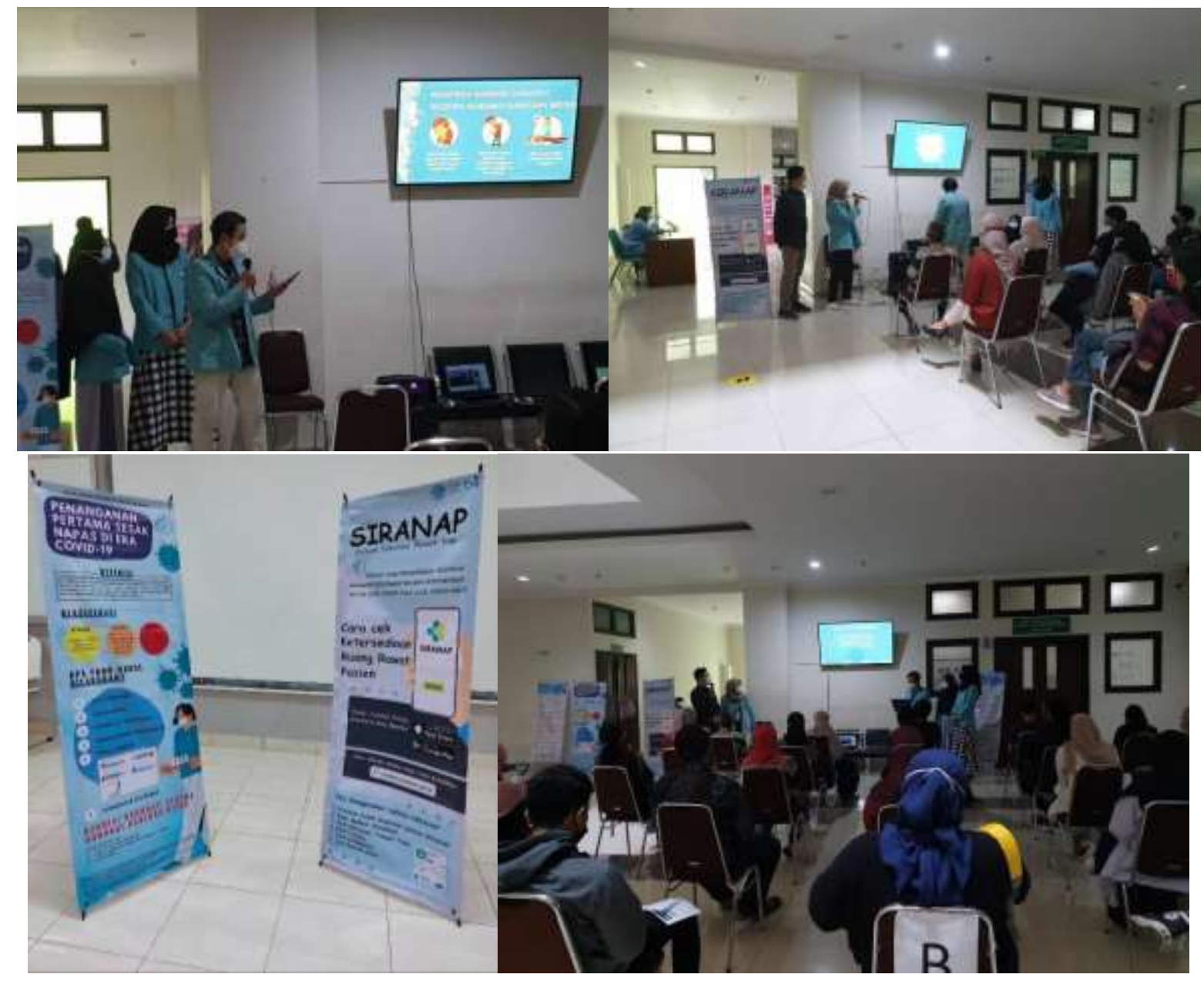

Gambar 2. Edukasi tentang Sesak Napas dan SIRANAP secara Luring 


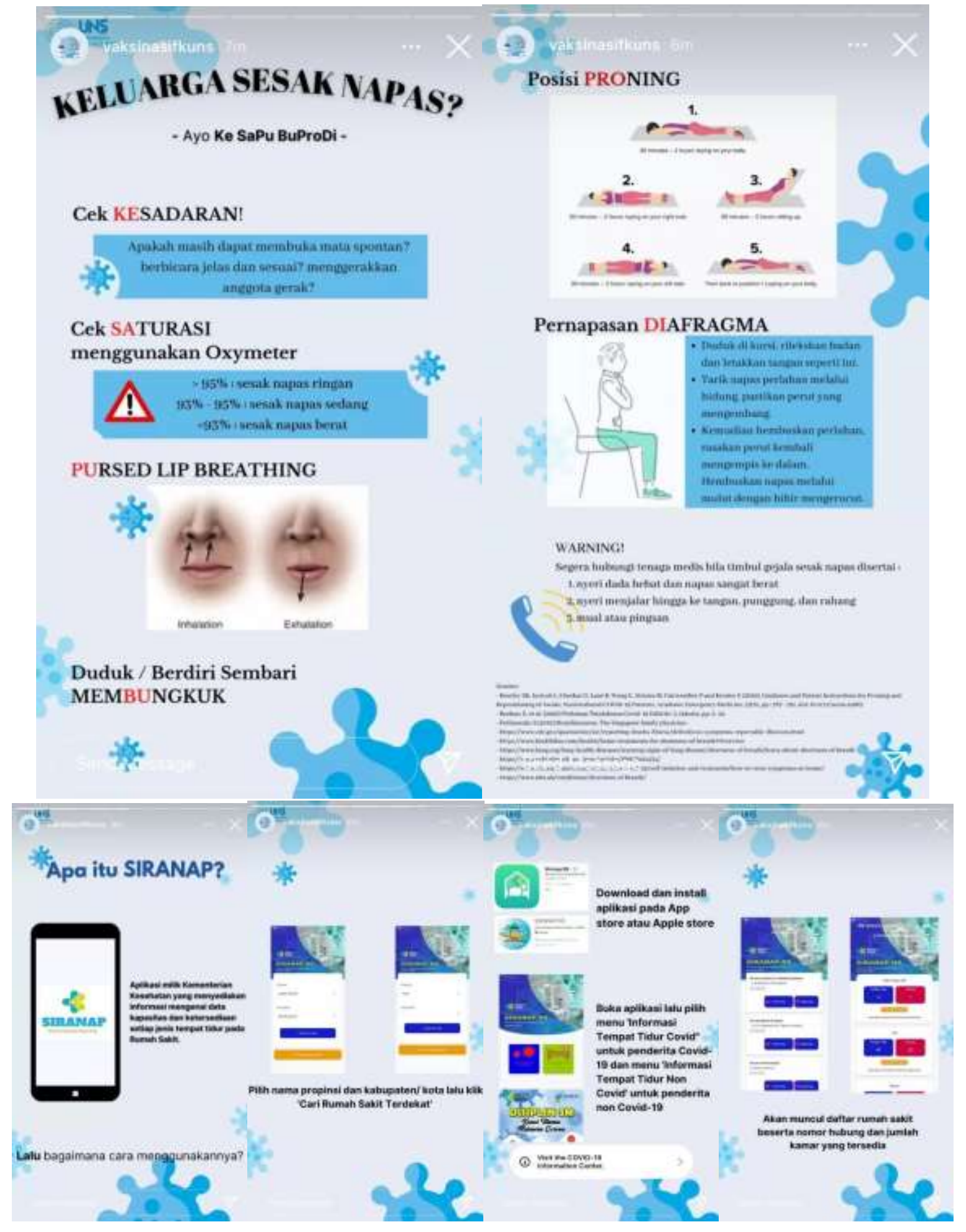

Gambar 3. Edukasi tentang Sesak Napas dan SIRANAP secara Luring 


\section{c. Hasil Monitoring dan Evaluasi}

Walaupun secara umum pelaksanaan kegiatan vaksinasi maupun kegiatan projek kelompok berlangsung secara baik, masih banyak hal yang perlu dievaluasi. Evaluasi yang perlu dilakukan pada kegiatan vaksinasi diantaranya masih banyaknya peserta yang datang di FK UNS untuk melakukan vaksinasi tanpa sebelumnya mengisi formulir Google seperti yang telah diinformasikan. Hal tersebut membuat panitia harus meng-input data secara manual sehingga membutuhkan waktu yang lama sehingga flow peserta lain menjadi lambat dan lebih berisiko untuk terjadi salah ketik. Peserta yang belum mendaftar melalui formulir Google juga belum diseleksi oleh tim Humas dan IT sehingga riwayat penyakit yang seharusnya tidak diperbolehkan untuk vaksin tidak terseleksi.

Salah satu hal yang perlu diapresiasi dalam kegiatan vaksinasi adalah keterampilan panitia untuk mengarahkan peserta melewati berbagai alur vaksinasi seperti yang telah disebutkan di atas. Hal tersebut dilakukan dengan menaruh papan penunjuk dan memberikan instruksi langsung pada peserta. Efisiensi waktu dapat tercipta dari peserta yang tertib. Ketangkasan panitia di setiap alurnya juga memperlancar jalannya vaksinasi dari awal sampai akhir. Adanya sistem yang terintegrasi dari bagian registrasi hingga administrasi pasca vaksinasi membuat data lebih mudah dipantau dan pelaporan menjadi akurat.

Pelaksanaan kegiatan kelompok kecil berupa edukasi ke masyarakat juga memberikan respon yang baik. Beberapa hal yang patut dievaluasi antara lain ukuran media saat edukasi daring yang tidak cukup besar membuat peserta yang berada di belakang kesusahan dalam membaca media yang disediakan. Penyebarluasan materi sesak napas dan SIRANAP melalui Instagram pribadi masingmasing anggota sealigus Instagram vaksinasifkuns merupakan langkah yang tepat dilakukan karena masyarakat yang dapat dijangkau menjadi lebih luas.

\section{Kesimpulan}

Program vaksinasi COVID-19 merupakan salah satu bentuk upaya penyediaan layanan kesehatan dalam rangka mitigasi wabah COVID-19. Pemaksimalan kegiatan pelengkap seperti kampanye, sosialisasi, dan penyuluhan dengan metode yang dimodifikasi untuk menyesuaikan keadaan pandemi dapat dilakukan untuk menunjang pelayanan kesehatan yang sedang berjalan. Mahasiswa kesehatan sebagai generasi penerus dapat melibatkan diri dan memberikan kontribusi di komunitas dalam penanganan COVID-19 sesuai dengan kapasitas yang dimiliki. 


\section{Daftar Pustaka}

Badan Pengawasan Obat dan Makanan (BPOM). (2021, Maret 9). Badan POM Terbitkan Emergency Use Authorization Vaksin AstraZeneca. Dipetik Agustus 29, 2021, dari Badan POM: https://www.pom.go.id/new/view/more/ pers/594/Badan-POM-TerbitkanEmergency-Use-Authorization-VaksinAstraZeneca.html

Badan Pengawasan Obat dan Makanan (BPOM). (2021, Juli 15). Badan POM Terbitkan EUA Comirnaty (Vaksin COVID-19 Pfizer) Sebagai Vaksin Kedua Platform mRNA. Dipetik Agustus 29, 2021, dari Badan POM: https://www.pom.go.id/new/view/more/ pers/618/Badan-POM-Terbitkan-EUAComirnaty--Vaksin-COVID-19-Pfizer--Sebagai-Vaksin-Kedua-PlatformmRNA.html

Badan Pengawasan Obat dan Makanan (BPOM). (2021, Febuari 16). Badan POM Terbitkan EUA Vaksin COVID-19 Produksi Bio Farma. Dipetik Agustus 29, 2021, dari Badan POM: https://pom.go.id/new/view/more/berita/ 21226/Badan-POM-Terbitkan-EUAVaksin-COVID-19-Produksi-BioFarma.html

Badan Pengawasan Obat dan Makanan (BPOM). (2021, April 30). Penuhi Cakupan Jumlah Penduduk Indonesia, Badan POM Terbitkan EUA Vaksin COVID-19 Produksi Sinopharm. Dipetik Agustus 29, 2021, dari Badan POM: https://www.pom.go.id/new/view/more/ pers/610/Penuhi-Cakupan-JumlahPenduduk-Indonesia--Badan-POMTerbitkan-EUA-Vaksin-COVID-19Produksi-Sinopharm.html
Badan Pengawasan Obat dan Makanan (BPOM). (2021, Agustus 25). Badan POM Kembali Terbitkan EUA untuk Vaksin COVID-19 Sputnik-V. Dipetik Agustus 29, 2021, dari Badan POM: https://www.pom.go.id/new/view/more/ pers/620/Badan-POM-KembaliTerbitkan-EUA-untuk-Vaksin-COVID19-Sputnik-V.html

Balai Pengembangan Sumber Daya Manusia dan Penelitian Komunikasi dan Informatika Kementrian Informasi. (2020). Survei Perilaku Masyarakat Terkait Penyebaran Hoaks COVID-19 (Coronavirus). Dipetik Agustus 29, 2021, dari https://balitbangsdm.kominfo.go.id/publi kasi_638_19_222

Callaway, E. (2020, September 8). The coronavirus is mutating - does it matter? (Springer Nature Ltd.) Dipetik Agustus 29, 2021, dari Nature: https://www.nature.com/articles/d41586020-02544-6

Centers for Disease Control and Prevention (CDC). (2020). Vaccines \& Immunizations. Dipetik Agustus 29, 2021, dari https://www.cdc.gov/vaccines/basics/test -approve.html

Direktorat Jenderal Pencegahan dan Pengendalian Penyakit (Ditjen P2P). (2021, Januari 13). Program Vaksinasi COVID-19 Mulai Dilakukan, Presiden Orang Pertama Penerima Suntikan Vaksin COVID-19. Dipetik Agustus 29, 2021, dari Direktorat Jenderal Pencegahan dan Pengendalian Penyakit (Ditjen P2P): http://p2p.kemkes.go.id/programvaksinasi-covid-19-mulai-dilakukan- 
presiden-orang-pertama-penerimasuntikan-vaksin-covid-19/

Food and Drug Administration (FDA). (2018). The Drug Development Process Step 3: Clinical Research. Dipetik Agustus 29, 2021, dari https://www.fda.gov/patients/drugdevelopment-process/step-3-clinicalresearch

Global Alliance for Vaccines and Immunization (GAVI). (2020, December 30). What are whole virus vaccines and how could they be used against COVID-19? Dipetik Agustus 29, 2021, dari Gavi The Vaccine Alliance:

https://www.gavi.org/vaccineswork/wha $\mathrm{t}$-are-whole-virus-vaccines-and-howcould-they-be-used-against-covid-19

Global Alliance for Vaccines and Immunization. (2020, Desember 23). What are nucleic acid vaccines and how could they be turned against COVID-19? Dipetik Agustus 29, 2021, dari Gavi The Vaccine Alliance:

https://www.gavi.org/vaccineswork/wha t-are-nucleic-acid-vaccines-and-howcould-they-be-used-against-covid-19

Kementrian Kesehatan Republik Indonesia. (2021). Frequently Asked Question (FAQ) Seputar Pelaksanaan Vaksinasi COVID-19. Dipetik Agustus 29, 2021, dari Website Ditjen Kesehatan Masyarakat Kementrian Kesehatan: https://kesmas.kemkes.go.id/assets/uploa ds/contents/others/FAQ_VAKSINASI_ COVID_call_center.pdf

Kementrian Kesehatan Republik Indonesia. (2021, Agustus 12). Penularan,Perawatan dan Kematian akibat COVID-19 pada Tenaga Kesehatan di DKI Jakarta, Januari-Juni 2021. Dipetik Agustus 29, 2021, dari
Sehat

Negeriku: https://sehatnegeriku.kemkes.go.id/wpcontent/uploads/2021/08/Studi-TerbaruEfektifitas-Vaksinasi.pdf

Lauring, A., \& Hodcroft, E. (2020, Januari 28). Genetic Variants of SARS-CoV-2-What Do They Mean? (American Medical Association) doi:10.1001/jama.2020.27124

Liang, L.-L., Kuo, H.-S., Ho, H., \& Wu, C.-Y. (2021). COVID-19 vaccinations are associated with reduced fatality rates: Evidence from cross-county quasiexperiments. Journal of Global Health, 11(05019). doi:10.7189/jogh.11.05019

Nasserie, T., Hittle, M., \& Goodman, S. (2021). Assessment of the Frequency and Variety of Persistent Symptoms Among Patients With COVID-19: A Systematic Review. Jama Netw Open, 4(5). doi:10.1001/jamanetworkopen.2021.114 17

Sari, H. P. (2021, Agustus 28). Kemenkes: Target 2 Juta Vaksinasi COVID-19 Per Hari pada Agustus Tak Tercapai. Dipetik Agustus 29, 2021, dari Kompas.com: https://nasional.kompas.com/read/2021/ 08/28/12323871/kemenkes-target-2-jutavaksinasi-covid-19-per-hari-padaagustus-tak-tercapai

Wang, N., Shang, J., Jiang, S., \& Du, L. (2020). Subunit Vaccines Against Emerging Pathogenic Human Coronaviruses. Front Microbiol., $\quad 11, \quad 298$. doi:10.3389/fmicb.2020.00298

World Health Organization (WHO) \& United Nations Children's Fund (UNICEF). (2020). Pelayanan kesehatan berbasis komunitas, termasuk penjangkauan dan kampanye, dalam konteks pandemi COVID-19. 
World Health Organization (WHO). (2020). Coronavirus. Dipetik Agustus 29, 2021, dari https://www.who.int/healthtopics/coronavirus\#tab=tab_1

World Health Organization (WHO). (2021). Coronavirus disease (COVID-19) pandemic. Dipetik Agustus 29, 2021, dari https://www.who.int/emergencies/diseas es/novel-coronavirus-

2019? adgroupsurvey $=\{$ adgroupsurvey $\}$ \&gclid=Cj0KCQjwvaeJBhCvARIsABg TDM4gLvTeZ1OnCTLSuqSNIfWjOPsz QmTJz7mlAyWCXIoE1YhS8KRMb1sa AreLEALw_wcB
World Health Organization (WHO). (2021, Agustus 27). COVID-19 vaccine tracker and landscape. Dipetik Agustus 29, 2021, dari WHO: https://www.who.int/publications/m/ite $\mathrm{m}$ /draft-landscape-of-covid-19candidate-vaccines

Zhu, F., Guan, X., Li, Y., Huang, J., Jiang, T., Hou, L., . . . Chen, W. (2020). Immunogenicity and safety of a recombinant adenovirus type-5-vectored COVID-19 vaccine in healthy adults aged 18 years or older: a randomised, double-blind, placebo-controlled, phase 2 trial. Lancet, 396(10249), 479-488. 